\title{
The Color Purple and Women's Time
}

\author{
Kamelia Talebian Sedehi \\ Universiti Putra Malaysia, Malaysia \\ Rosli Talif \\ Universiti Putra Malaysia, Malaysia \\ Wan Roselezam Wan Yahya \\ Universiti Putra Malaysia, Malaysia \\ Hardev Kaur \\ Universiti Putra Malaysia, Malaysia
}

\begin{abstract}
In Women's Time, Julia Kristeva asserts that women have been deprived of linear time for progress and improvement; they have been confined to circular time, which is a vicious circle of repetition; therefore she asked for the existence of a third generation of feminists to focus on linear time and to provide the ground for women's social as well as domestic roles. She mentions that the third feminists' duty is to pay attention to the individuality of each woman. In The Color Purple, Alice Walker's female protagonist, Celie, revolts against fixed gender roles. She unites with other female characters and has a sisterhood relationship. This article intends to focus on the effect of patriarchal system on women. Moreover, it will highlight sisterhood and its effect on women's individuality and social roles. As such, this article intends to focus on Julia Kristeva's notion of women's time and the way Celie intends to follow her desires. The attention to Celie's passions and desires in life helps her to know herself better.
\end{abstract}

Index Terms-Alice Walker, The Color Purple, Julia Kristeva, women's time, gender roles

\section{INTRODUCTION}

Alice Walker wrote The Color Purple in 1982 and in 1985, Steven Spielberg made The Color Purple into a movie of the same name and this added to Alice Walker's fame. "Alice Walker's The Color Purple is one of the most controversial and revolutionary black female authored texts in the American and African-American literary canons" (Taylor, 2007, p. 10). In The Color Purple, Walker explores the themes of gender discrimination, racial discrimination, rape and sexism. She displays how gender discrimination can influence black women's subjectivity and lead them into misery. This novel indicates how racism influences black people's social and personal lives. As black men are in the margins of white society, black women are in the margins of the margins, among black men and whites. In fact, black women are like white and black men's slaves. As Cheung observes, "some of these women are, moreover, thrice muted, on account of sexism, racism and a 'tonguelessness' that results from prohibitions or language barriers" (Cheung, 1988, p. 163). In order to fight against barriers, Walker questions the patriarchal system and sexist society; therefore, one can assume that The Color Purple is "an ant-story: anti-patriarchal and anti-sexist" (Hall, 1992, p. 90).

One should notice that Alice Walker's grandmother's stories influenced her and she became interested in writing as she grew up with this kind of oral tradition background. Besides, she observed the blacks' condition, especially black women's condition and marginalization, in American society; therefore, she put black characters at the centre of her novels. In the The Color Purple, Alice Walker focuses on Celie, who is trapped by racist and sexist oppression and the way she seeks to define herself is through the use of language. Celie "is an 'invisible woman,' a character traditionally silenced and effaced in fiction; and by centering on her, Walker replots the heroine's text" (Abbandonato, 1991, p. 1106). She gives voice to Celie and permits her to express all the miseries she has undergone.

As black women always live under patriarchal rules, they do not regard themselves as free people who can control their own lives. The protagonist of The Color Purple, Celie, believes that the only way to survive in her husband's house is to obey his rules, to tolerate the beatings and to remain silent. However, she finds her voice and starts to stand up for her rights. That is the reason why Maples believes that:

Alice Walker's The Color Purple is a liberative text that showcases a method by which her character, and ostensibly African-Americans, can situate themselves within the world. It follows that the novel is inherently related to the notion of growth. (Maples, 2007, p. 1)

In fact, Celie's subjectivity develops as she perceives her desires in life and intends to follow them with the help of other characters; she grows through the process of writing and befriending other characters. One should notice that, Celie is a character that Alice Walker brings into fiction from real life, as Walker observed the way her parents were influenced by racism and how they were forced to work as sharecroppers on white men's farms. Moreover, she heard 
about racial and sexual discrimination; therefore, she displays all these tensions in her novels. She allowed Celie to come into her consciousness, cope with her life and, moreover, take action against discrimination. In addition, Walker enables her to redefine herself with other female characters' help. The Color Purple is representative of "a woman's struggle toward linguistic self-definition in a world of disrupted signs: Celie is imprisoned, alienated, sexually abused and driven into semiotic collapse" (Abbandonato, 1991, p. 1106). Moreover, "Celie is silenced by an external source and experiences the nullification of subjectivity and internal voice" (Cutter, 2000, p. 164), but throughout the novel she starts to find her voice and express herself. Although Celie was not able to communicate with other characters, she vocalizes her miseries as soon as she feels secure within sisterhood bond with other characters; moreover, she starts expressing herself. In a series of letters, Celie starts to express her horrible life, because from the very beginning she is forbidden to talk about her misery to others by her stepfather and as she needs to express it, she uses letters to express herself.

Walker enables the reader to enter into the private thoughts and emotional state of her traumatized, guilt and shameridden, and depressed fourteen-year-old protagonist, who has been repeatedly raped and impregnated by the man (Alphonso) who she believes to be her biological father. (Proudfit, 1991, p. 17)

The reader can perceive Celie's private emotions from her tongue and through the letters she addresses to God. As these letters provide a personal diary for the reader, the reader can hear Celie's personal emotions.

Besides, one should notice that Celie, as a fourteen- year- old girl, was raped by her stepfather and Walker emphasizes that she describes:

...the brutal sexual violence done to a nearly illiterate black woman child who then proceeds to write down what has happened to her in her own language from her own point of view. She does not find rape thrilling; she thinks the rapist looks like a frog with a snake between his legs. How could this not be upsetting? Shocking? How could anyone want to hear this? (Hamilton, 1988, p. 382)

As Celie was a child, while she was raped, she hates all men and their sexual member; therefore, she cannot communicate men or enjoy sexual relationship. As the main discussion in The Color Purple centres on the war between the sexes, this article will focus on how Celie makes progress in society and gains a social role in addition to her domestic role, which is the main topic of discussion of Julia Kristeva in Women's Time.

In addition to focusing on women's time, this article will investigate the way sisterhood helps women to support each other both emotionally and financially. Each woman has her own desires in life, and this study will shed light on how this sisterhood leads to Celie's freedom of choice and attaining a social role. Moreover, this study will indicate how Celie starts to fight against the patriarchal system that has exploited her all these years, either physically, psychologically or both, through sisterhood. "Walker always emphasizes the importance of "sisterhood" in black women's emancipation" (Singh \& Guphta, 2010, p. 218). As Alice Walker puts black women at the centre of The Color Purple, this study will show how Celie gains self-realization with the help of sisterhood; sisterhood helps her to perceive her desires, respect them, follow them in society, search for a social role and achieve it.

\section{DISCUSSION}

Based on James Joyce "Father's time and mother's species," Julia Kristeva assumes that women have a cyclical life in which everything is repeated and their life is repetition of repetitions. However, men have a linear time in which they can improve their life and make progress.

Voice without body, body without voice, silent anguish choking on the rhythm of words, the tones of sounds, the colors of images, but without words, without sounds, without images; outside time, outside knowledge, cut off forever from the rhythmic, colorful violent changes that streak sleep, skin, viscera: socialized, even revolutionary, but at the cost of the body; body crying, infatuating, but at the cost of time; cut- off; swallowed up. (Kristeva, 1986, p. 16)

As women are deprived of time, linear time, they could not make progress in their life and society and they cannot express themselves easily. In fact, in the patriarchal society women are scarified as they are considered "the other race" (Kristeva, 1986) as they are considered inferior to men.

As such, Julia Kristeva notices that early feminism highlighted similarities between men and women in order to demand the same rights and privileges that men have. On the other hand the next generation of feminists emphasized the women's uniqueness. Kristeva believes that women are in subordinate position to power and language; therefore, the feminists intend to infiltrate the social order and then challenge it. The first generation of feminists demanded the same time that men inhabited; the time of linear history; the time of progress and accomplishments. Before that, women inhabited the household in which the time was cyclical. The first generation of feminists asked for the linear time; the time of progress, production and creation. The first generation of feminists intended to join the men's linear time rather than overturning this time.

The second generation of feminists focused on the difference between men and women and they applied psychoanalytic theory to express that the symbolic order is founded on castration anxiety. Women suffer from imaginary castration; therefore, they should enter the social symbolic order to fulfill this castration anxiety. The feminists of the second generation claim that in the sexist society the psycho-symbolic structure dominates which asks for separation of the people. Unlike the first generation who emphasized the similarities, the second generation highlighted the differences and they mainly focused on the womanly values which have been rejected throughout years. 
The second generation intends to transgress the existing system. Although the first generation attempted to gain linear time, the second generation embraced the cyclical time and women as the producers of species. Besides, unlike the first generation which spurns mothering, the second generation cherishes mothering. The second generation's emphasis on woman as a general notion puts individuality of each woman into danger. As Kristeva states,

To believe that one is a woman is almost as absurd and obscurantist as to believe that one is a man....I therefore understand by woman that which cannot be represented, that which is not spoken, that which remains outside naming and ideologies (Lechte \& Margaroni, 2004).

That is the main reason why she is against the second generation of feminists as they highlight woman and forget about the woman as human being.

As neither of these two generations focused on the singularity of each woman, Kristeva mentioned that the third generation of feminists should mainly focus on individuality of each woman. The third generation of feminist will reconcile women's desire for motherhood as well as their desire for linear time. Therefore, the third generation is expected to focus on each woman's multiple desires. Neither of the previous generations considered women both as producers of species and producers of the culture; body and society. This change in thought needs a revolt against previous preconceptions about women as producers of species; however Lechte and Margaroni notice that "revolt becomes the essential gesture in the constitution of individuality" (2004).

In The Color Purple Celie intends to attain this linear time of progress and improvement. The Color Purple deals with Celie's fight for progress and individuality. She intends to enter society, follow her dreams and achieve them. In Kristeva's words, women should revolt if they intend to have pleasure, as they achieve happiness by "confronting obstacles, prohibitions, authority, or law that allows" them to realize themselves as "autonomous and free" (Kristeva 2000, p. 7). Here, Celie should confront patriarchal system which confined her for long time. Moreover, the revolt transforms invisible Celie into visible one. In fact:

The Color Purple, Alice Walker's novel of black feminist awakening, is a model for the reconstruction of a black feminist literary tradition. If the existence of such a tradition had previously been marked by the "white page" and historical silence, Walker subverts the space by embracing the absence. (Hall, 1992, p. 1)

Alice Walker puts black invisible women, who are absent from classical literature and history, into the spotlight and permits them to speak and take action.

As the novel unfolds, Celie's stepfather, whom Celie considers as her biological father, warns her not to tell anyone about the fact that he rapes her. As a result, Celie is obliged to remain silent, but she needs to tell someone; therefore, she writes letters to God and explains all the misery which has been forced upon her. Language is in the hands of men and they dominate women with it; men decide what, to whom and where women can express themselves, as Kristeva holds, women are "excluded from the single true and legislating principle, from the Words" (Kristeva, 1993, p. 21) because without words, women cannot have independent personality. Men force women not to use language as speaking helps them to gain a sense of identity. In fact, "no person is your friend who demands your silence, or denies your right to grow" (2012, p. 1). Therefore, men intend to silence women as they are afraid of women's progress and improvement. The act of writing is a kind of revolt, as Celie must not tell anyone about the rapes. In fact, Celie experiences male bullying and domination when she is raped at the age of fourteen (Hankinson, 1997, p. 321). Besides, as Kristeva notices, "there is no time without speech"; and in this novel, Celie should start using language to attain linear time (Kristeva, 1993, p. 35), individuality and social role. She intends to write in order to express her desire and ambitions within language and ask for her social rights.

When the stepfather grows tired of Celie, he encourages Mr._ to marry her. After their marriage, one day, Tobias, Mr.'s brother, visits Celie and Mr._, and Shug, Mr.'s former lover. They talk about different women. Shug holds that "all women not alike, Tobias" (Walker, 2004, p. 55). This speech emphasizes the fact that although women may have the same sex, they are different in their thoughts, feelings and desires. Each individual woman has her own desires and fights for them However, in patriarchal families, women's desires are not respected.

In The Color Purple, female characters help each other to live a comfortable life and follow their feminine desires, e.g. as Shug understands that Mr._ beats Celie, she says that she "won't leave" until she knows that "Albert [Mr.] won't even think about beating" her (Walker, 2004, p. 72). The women bond together and ameliorate each other's situations. If men force women to obey them and restrict their freedom, women provide each other with liberty and love. They know how to support, encourage and help each other.

As women have been ignored, misrepresented and mistreated in literature and history, in this novel, Walker intends to highlight women's suffering and show how they can get rid of the misrepresentations by proving their abilities, and how they gain power through relationships with other female characters. For example, Shug realizes that Celie does not have any sexual feelings when she sleeps with Mr.. Moreover, she perceives that Celie does not know her own body; therefore, Shug decides to make Celie familiar with her body.

Listen, she say, right there in your pussy is a little button that gits real hot when do you know what with somebody. It git hotter and hotter and then it melt. That the good part. But other parts good too, she says. Lot of sucking go on there, and there, she says. Lot of finger and tongue work. (Walker, 2004, p. 74) 
In order to express her desires, Celie should first know them. One of these desires, which have been silenced for years, is sexual desire, and Shug helps Celie to recognize it in herself. "Here, take this mirror and go look at yourself down there" (Walker, 2004, p. 74). In fact, one can consider:

...the evaluation of the female body as the site of self-awareness and self-esteem. Thus, in The Color Purple, a crucial moment in Celie's transformation comes when she perceives the beauty of her genitalia. (Byerman, 1985, p. 321)

Shug teaches Celie to enjoy herself, to know her body and to appreciate her female productive organs. In fact, "with Shug's encouragement, Celie's self reclamation begins as she sees her own genitals for the first time" (Pifer \& Slusser, 1998 , p. 48). For the first time, she perceives her sexual desires with the help of another woman. As a result of this repossession of her body, Celie is able to gain selfhood through spoken language. In fact, as she was forced to forget about rape, she was ignorant about her sexual organ as well. However, as soon as she knows her productive organs, she becomes able to express her repressed desires as well. Therefore, she informs Mr._ that she is going to join Shug in Memphis. She revolts against Mr._'s patriarchal ideology which restricts her all the time, and follows her dream of freedom with Shug. She enjoys her life as the possibility of revolt gives her happiness of being independent.

Besides helping Celie to get to know her body, Shug encourages Celie to perceive her talent for sewing and improving it. As a result of Shug's encouragement, Celie stands in front of Mr._. She does not intend to have a marginal position in her family. She verbalizes the words which have choked her all these years. She has suffered all these years and now she is ready to fight for her progress. In Kristeva's view, a woman is submitted to "a whole series of authorities: her own mother and father, her husband's mother and father, her husband, and, finally, her son" (Kristeva 1993, p. 194). Here, Celie has been restricted for years, first by her father and then by her husband. Now she feels free as she finds a friend on whom she can rely. She intends to liberate herself from her husband's dominance and follow her dreams. She is skilful at sewing pants and intends to do it when she goes to Memphis with Shug.

In addition to helping Celie recognize her sewing talent, Shug encourages Squeak to sing. As Squeak is supported by Shug, she gains courage and at last Squeak says, "I want to sing ... I need to sing" (Walker, 2004, p. 183). Squeak desperately wants to sing as singing is a way to express herself, her miseries and her problems. Even Shug, as a singer, revolts against people's biased thoughts. Women and men do not approve of her singing career and always belittle and humiliate her, but she does it because it is her personal desire. Kristeva notices that, "indeed, the time has perhaps come to emphasize the multiplicity of female expressions and preoccupations" (Kristeva, 1986, p. 18). Shug and Squeak like singing and Celie likes sewing, and these different desires make them different and unique in person.

Besides being a supportive friend, Shug is like a mother figure who guides women in their lives. All the female characters in this novel bond together and help each other. Squeak decides to sing and Sofia promises to take care of her daughter. Through bonding, women are able to improve their lives and follow their repressed talents and desires. These women "defend themselves with words; they discover their potential - sound themselves out through articulation" (Cheung, 1988, p. 162). Although, at first, Celie's talents and desires were silenced by her father and her husband, she learns to express herself, not only with Shug's help but also by observing Shug's courageous and determined personality.

When Celie sews pants and they become popular with her family and her friends, she becomes financially independent. Shug addresses Celie and says, "you making your living, Celie ... Girl, you on your own way" (Walker, 2004, p. 193). Now Celie stands on her own two feet and is on her way to making progress. She revolts against Mr._'s patriarchal ideology, fights for her freedom, follows her dream of sewing and makes progress through hard work. Through the relationships with other female characters, Celie is able to cast off the patriarchal dominance which silenced her all those years.

In The Color Purple, women tolerate racism, sexism and gender discrimination, but they unite with each other. Through sisterhood, women realize their talents, verbalize them and follow them As they have emotional supporters, they follow their dreams without worrying and then achieve their goals. As Haste asserts, by giving authenticity to female subjectivity there should be some ways to change women's view of themselves and males' view of women (Haste, 1994, p. 204). There should not be any preconception of women's subjectivity.

Men are against women's progress at first and are opposed to it, as they think that with women's power and success their manhood will be under question. As a result of patriarchy, they are blind to women and intend to put barriers in their way. As her sewing improves, Celie becomes wealthy and she returns home to wait for her sister and her children's arrival. At this time, Mr._ recognises his mistake and his mistreatment of her and starts supporting her. Mr._ sews pants with Celie and gives her some ideas about shirts which are suitable to go with Celie's pants. Moreover, Harpo supports Sofia in her job and takes care of their daughter while Sofia is away. In fact, women have had marginal positions, both in their families and in society, and this marginality "allows us to view [the] repression of the feminine in terms of positionality rather than essences" (Johnson, 2002, p. 170); in essence, women are not inferior or weaker, but in society they are considered as such by patriarchal system. However, in The Color Purple, women start to bond together and then men join them, and that is the main reason why progress happens. "By thinking and acting women can overcome man-made barriers to their humanity" (Dawson, 1987, p. 132). This novel envisions a better future for black people through union. In fact,

...in "in Search of Our Mother's Gardens," Walker speaks about three types of black women: the physically and psychologically abused black women, the black women who are torn by contrary instincts, and the new black woman, who re-creates herself out of the creative legacy of her maternal ancestors. (Dawson, 1987, p. 194) 
This novel reflects Walker's new black women who verbalize their needs and go after them. In fact, through sisterhood, female characters get rid of their marginalized positions in the family and recreate their subjectivity through recognizing their needs and talents, expressing them and finding ways to improve them.

\section{CONCLUSION}

To sum up, Julia Kristeva's notion of women's time highlights women's confinement in house and their deprivation of social roles and their overlooked desires. In The Color Purple, Alice Walker provides an opportunity for black female characters to defend themselves in patriarchal system and gain individuality and social role. As a result, Celie is transformed from a timid non-fighter to a courageous fighter who stands up for her rights. As a result of her revolt against patriarchal ideology, she achieves linear time and enters the sewing industry. She does not devote all her time to do household chores, rather she enters the business of sewing and makes financial progress. However, The Color Purple does not eliminate men, as it considers their transformation too. The transformation of men and the improvement in women's situations in this novel envision a better future for black people. Women perceive that through sisterhood they can realize their dreams, follow them in society and achieve them. Therefore, the secret to attaining linear time is sisterhood in this novel.

\section{REFERENCES}

[1] Abbandonato, L. (1991). "A View from 'Elsewhere': Subversive Sexuality and the Rewriting of the Heroine's Story in The Color Purple." PMLA. Publications of the Modern Language Association of America 106.5: 1106-.ProQuest Central. Web. 3 Feb. 2013.

[2] Byerman, K. E. (1985). Fingering the Jagged Grains: Tradition and Form in Recent Black Fiction. Athens: Georgia, The University of Georgia Press.

[3] Cheung, K. (1988). ""Don't Tell": Imposed Silences in The Color Purple and the Woman Warrior." PMLA. Publications of the Modern Language Association of America 103.2: 162-.ProQuest Central. Web. 3 Feb. 2013.

[4] Cutter, M, J. (2000). "Philomela Speaks: Alice Walker's Revisioning of Rape Archetypes in The Color Purple." MELUS 25.3: 161-80. ProQuest Central. Web. 3 Feb. 2013.

[5] Dawson, E. J. W. (1987). "Images of the Afro-American Female Character in Jean Toomer's Cane, Zora Neale Hurston's Their Eyes Were Watching God and Alice Walker's The Color Purple." University of South Florida. United States, District of Columbia: ProQuest Dissertations \& Theses (PQDT). Web. 3 Feb. 2013.

[6] Hall, J. C. (1992). "Towards A Map Of Mis (Sed) Reading: The Presence Of Absence In The Color Purple." African American Review 26.1: 89. Academic Search Premier. Web. 2 Nov. 2012.

[7] Hamilton, C. (1988). "Alice Walker's Politics or Politics of The Color Purple." Journal of Black Studies a8.3: 379-91. SCOPUS. Web. 3 Nov. 2012.

[8] Hankinson, S. L. (1997). "From Monotheism to Pantheism: Liberation from Patriarchy in Alice Walker's The Color Purple." The Midwest Quarterly 38.3: 320-8. Arts \& Humanities Full Text; ProQuest Central. Web. 4 Feb. 2013.

[9] Haste, H. (1994). The Sexual Metaphor. United States: Harvard University Press.

[10] Johnson, T. (2002). "Archaeologies and Utopias: Reassessing Kristeva's Relevance to Feminist Literary Practice." Feminist Theory 3.2: 169-81. Sociological Abstracts. Web. 4 Feb. 2013.

[11] Kristeva, J. (1993). About Chinese Women. New York: Marion Boyars Publishers.

[12] Kristeva, J. (2000). The Sense and Non-Sense of Revolt. New York: Columbia University Press.

[13] Kristeva, J. (1986). "Women's Time." Trans. Alice Jardin and Harry Blake. The Kristeva Reader. Ed. Toril Moi. New York: Columbia Up. 187- 213

[14] Lechte, J, \& Margaroni, M . (2004). Julia Kristeva: Live Theory. New York: Continuum.

[15] Maples, M. D. (2007). "Purple as Symbol and Characterizer in Alice Walker's "The Color Purple"." University of South Alabama. United States, Alabama: ProQuest Dissertations \& Theses (PQDT). Web. 3 Feb. 2013.

[16] Walker, A. (2012). No person is your friend who demands your silence, or denies your right to grow. Cape Times 27. Retrieved from: http://search.proquest.com/docview/952841057? accountid=27932.

[17] Pifer, L., \& Slusser, T. (1998). "'Looking at the Back of Your Head": Mirroring Scenes in Alice Walker's The Color Purple and Possessing the Secret of Joy." MELUS 23.4: 47-57. ProQuest Central. Web. 3 Feb. 2013.

[18] Proudfit, Ch. L. (1991). "Celie's Search for Identity: A Psychoanalytic Developmental Reading of Alice Walker's The Color Purple." Contemporary Literature 32.1: 12-.ProQuest Central. Web. 3 Feb. 2013.

[19] Singh, S., \& Guphta, S. (2010). Celie's Emancipation in The Color Purple. International Journal of Humanities and Social Sciences, 2: 218-222.

[20] Taylor, N. J. (2007). "The Camera is Mightier than the Pen: Resistance, Revolution, and Revision in the Film Adaptations of Alice Walker's "The Color Purple", Zora Neale Hurston's "Their Eyes were Watching God", and Toni Morrison's "Beloved"." Howard University, 2007. United States, District of Columbia: ProQuest Dissertations \& Theses (PQDT). Web. 3 Feb. 2013.

[21] Walker, A. (2004). The Color Purple. Great Britain: Phoenix Paperback.

Kamelia Talebian Sedehi received her B.A. and M.A. in English Literature from University of Isfahan. At the present time, she is a PhD candidate at Universiti Putra Malaysia. Her publications include: The Melancholic Subject and The Bluest Eye, Beloved and Kristevan Melancholic Subject, and Natural Selection and The Cage. She has presented at various national and international conferences and is an experienced university lecturer and teacher. 
Rosli Talif is an associate professor of English Studies at the Department of English, Faculty of Modern Languages and Communication, Universiti Putra Malaysia (UPM). His main interests include issues in literature and gender, gender roles in literature and the media, gender concerns in children's literature, and language policy and planning in Malaysia. His publications interlink language and literature while re-examining existing paradigms that affect the way we conceptualize the roles, functions, and developments of language and literature in society.

Wan Roselezam Wan Yahya is Associate Professor of English Literature at the Department of English, Faculty of Modern languages and Communication, Universiti Putra Malaysia. Her research interests and publications are inter-disciplinary by nature, such as in literature and gender, literature and psychoanalysis, literature in English as a Second Language, and ecocritical studies of literature.

Hardev Kaur PhD is currently a Senior Lecturer attached to University Putra Malaysia. She is the Post Graduate Course Coordinator of English Literature in The English Department. A graduate from the Islamic International University, her doctoral work examined the reconciliation process in Post Apartheid South African novels. Her research interest includes the politics and social issues in novels and Trauma Theory. She teaches courses on Post Nuclear American and British novels. 